www.jmscr.igmpublication.org

Impact Factor (SJIF): 6.379

Index Copernicus Value: 71.58

ISSN (e)-2347-176x ISSN (p) 2455-0450

crossref DOI:_https://dx.doi.org/10.18535/jmscr/v6i4.137

Journal Of Medical Science And Clinical Research

\title{
Penile Circumferential Fascio- Cutaneous Onlay flap urethroplasty for Complex long Anterior Urethral Strictures. A Prospective Single centre experience with Five years follow up
}

\author{
Authors \\ Syed Sajjad Nazir, Naveed Khan, Syed Adil Bashir, Muneer Khan \\ Department of Urology, Superspeciality Hospital, Govt Medical College Srinagar, Kashmir, J\&K, India \\ Corresponding Author \\ Dr Syed Sajjad Nazir \\ Assistant Professor, Department of Urology, Superspeciality Hospital, Government Medical College \\ Srinagar, Kashmir, J\&K, India \\ Email:drsyedsajjad@yahoo.co.in/syedsajjadnazir@gmail.com \\ Phone No: 0192434272, Mobile: 9419585858/9796739077/ 7006961650
}

\begin{abstract}
Introduction: Long, complex strictures of the anterior urethra are a challenge and a variety of techniques to reconstruct complex anterior urethral strictures are presently available. Penile Circumferential fasciocutaneous flap urethroplasty is a useful technique for a long anterior urethral stricture due to the flap's hairless nature, mobility and ample length.

Aims and Objectives: To assess the surgical outcomes of urethroplasty for a complex anterior urethral stricture, using a penile Circumferential fasciocutaneous Flap like postoperative complications, stricture free period.

Material \& Methods: Between 2007 to 2013, A total of 86 patients with long anterior urethral strictures of more than $5 \mathrm{cms}$ in the age group of 20-65 yrs were subjected to circumferential penile skin urethroplasty.

Results: The median intraoperative stricture length was $6.5 \mathrm{cms}$ with median operating time of 100 minutes (90-145 min) and blood loss of $100 \mathrm{ml}$. All patients had five years of follow up. Year wise success rate was $92 \%, 89 \%, 84 \%, 80 \%$ \& $79 \% .12 .72 \%$ of the patients had recurrent strictures.

Conclusion: Penile circular fasciocutaneous flap urethroplasty is a useful method for the reconstruction of a long anterior urethral stricture. A sufficient healthy margin should be acquired for better surgical results due to the fact that most recurrence occurs at the junction of the flap.

Keywords: Penis, Surgical flaps, Urethral stricture.
\end{abstract}

\section{Introduction}

Long, complex strictures of the anterior urethra are a challenge and a variety of techniques to reconstruct complex anterior urethral strictures are presently available ${ }^{(1,2)}$. However without question, excision of the stricture and primary, spatulated, end-end reanastomosis is the gold standard. For more complex strictures of more than $2 \mathrm{cms}$ in length, tissue-transfer techniques are frequently used. Of the numerous procedures that reconstructive urologists have in their arsenal, the most successful are full-thickness free grafts 
(genital skin, bladder mucosa, or buccal mucosa, lingual mucosa) or pedicle- based flaps that carry a skin island. While a graft derives its blood supply from the surrounding tissue, a flap is transferred to the recipient site with its blood supply intact. The penile circumferential fasciocutaneous flap, as first described by McAninch $^{(3)}$ produces excellent cosmetic and functional results. It provides an ample length (usually $13-15 \mathrm{~cm}$ ) of non-hirsute, well vascularized tissue that be used throughout the entire urethra. It can be applied as an onlay procedure or, if necessary, tabularized for replacement. Complications have been minimal and long term cosmetic and functional results have been excellent. Unfortunately, there have been no studies on the surgical outcomes of penile circumferential fasciocutaneous flap urethroplasty in Kashmiri patients. Therefore, we performed a prospective evaluation of patients who underwent urethroplasty for anterior urethral strictures using a penile fasciocutaneous flap to report our experience with the surgery and to assess the factors affecting the surgical outcome.

\section{Aims and Objectives}

To assess the surgical outcomes of urethroplasty for a complex anterior urethral stricture, using a penile Circumferential fasciocutaneous Flap like postoperative complications, stricture free period.

\section{Material \& Methods}

The study was conducted on the patients who presented to our department between January 2007 to March 2013 with long anterior urethral strictures of more than $5 \mathrm{cms}$ in length. A total of 86 patients in the age group of 20-65 yrs, were enrolled. All patients underwent preoperative evaluation in the form of complete careful history, medical examination, basic laboratory investigations, ultrasound, uroflowmetry, cystoscopic examination and radiological investigations like RGU/MCU. Data was entered in excel and presented in percentages.

\section{Results}

In the study, A total of 86 patients in the age group between 20-65 years, with median age of 29 yrs were enrolled from January 2007 to March 2013. All the patients were males with circumcised penis with no previous surgical intervention (urethroplasty) for urethral stricture. 48 patients had preoperatively suprapubic diversion for urinary retension, while rest of the patients had obstructive symptoms. The Etiology of the stricture were Trauma $\rightarrow 34$ pts (39.53\%), catheter induced / Instrumentation $\rightarrow 29$ pts $(33.72 \%)$, Infections $\rightarrow 10$ pts $(11.62 \%)$ and Idiopathic in 13 pts $(15.11 \%)$ Table1. The average stricture length was $6.5 \mathrm{cms}$ (range 5-14 cms) while the operative time was $90-145$ minutes (average $105 \mathrm{~min}$ ). The average blood loss was 85 $\mathrm{ml}$ (range $65-110 \mathrm{ml}$ ). The average hospital stay was 3 days (range 2-5 days). Catheter was kept for 21 days +/- 10 days and removed only when there was no leakage seen on pericatheteric study which was performed on 21St day. There were no significant early postoperative complications like penile necrosis or infection of donor site. Late complications included recurrent stricture in 11 pts, urethrocutaneous fistula in 1 pt, Erectile dysfunction in 2 pts, post micturation dribbling in 3 pt, recurrent UTI in 5 pts, dysuria in 7 pts and hair follicle growth in 2 pts (Table 2). Recurrent strictures were seen only in those patients who had supra pubic diversion, secondary to severe spongiofibrosis for a variable length of the stricture especially in catheter induced strictures. Failures were considered if any patient required dilatation, OIU, obstructive LUTS, evidence of stricture on urethrography. All patients were followed for $5 \mathrm{yrs}$ with first RGU done at 3 months, followed by uroflowmetry and objectively 3 monthly for 5 yrs. Cystoscopic examination was done upto 5 years for every 3 monthly to see the changes in graft. Year wise stricture free success rate was $92 \%, 89 \%, 84 \%$, $80 \%$ and $79 \%$. (table 3 ). 
Table 1. Aetiology of Strictures

\begin{tabular}{|l|c|c|}
\hline Trauma & $34 \mathrm{pts}$ & $39.53 \%$ \\
\hline Catheter induced/ instrumentation & $29 \mathrm{pts}$ & $33.72 \%$ \\
\hline Infection & $10 \mathrm{pts}$ & $11.62 \%$ \\
\hline Idiopathic & $13 \mathrm{pts}$ & $15.11 \%$ \\
\hline
\end{tabular}

Table 2 Postoperative complications

\begin{tabular}{|l|c|c|}
\hline Complications & $\begin{array}{c}\text { Number of } \\
\text { patients. }\end{array}$ & Percentage \\
\hline Recurrent Strictures & 11 & $12.72 \%$ \\
\hline Urethro-cutaneous fistula & 1 & $1.16 \%$ \\
\hline Erectile dysfunction & 2 & $2.32 \%$ \\
\hline Post micturation dribbling & 3 & $3.48 \%$ \\
\hline Recurrent UTI & 5 & $5.81 \%$ \\
\hline Skin necrosis & nil & $0.00 \%$ \\
\hline Dysuria & 7 & $8.13 \%$ \\
\hline Hair follicle growth & 2 & $2.32 \%$ \\
\hline
\end{tabular}

Table 3 Year wise Stricture free rate

\begin{tabular}{|l|c|c|}
\hline Year & $\begin{array}{c}\text { Number of } \\
\text { patients }\end{array}$ & Percentage \\
\hline $1^{\text {st }}$ year & $80 \mathrm{pts} \mathrm{(86)}$ & $93.02 \%$ \\
\hline $2^{\text {nd }}$ year & $77 \mathrm{pts} \mathrm{(86)}$ & $89.53 \%$ \\
\hline $3^{\text {rd }}$ year & $73 \mathrm{pts} \mathrm{(86)}$ & $84.88 \%$ \\
\hline $4^{\text {th }}$ year & $69 \mathrm{pts} \mathrm{(86)}$ & $80.23 \%$ \\
\hline $5^{\text {th }}$ year & $68 \mathrm{pts} \mathrm{(86)}$ & $79.06 \%$ \\
\hline
\end{tabular}

\section{Discussion}

Traditionally penile skin flaps are preferred to free grafts for pendulous urethral reconstruction ${ }^{[4,5]}$. It is believed that a deficient corpus spongiosum and poor vascularity of the segment would not support graft take. Unlike bulbar strictures, length-sparing urethroplasty is essential in the reconstruction of a penile urethral stricture irrespective of the stricture length due to the risk of ventral curvature resulting from the shortened urethral length. Since the publication of the Orandi ${ }^{[6]}$ technique in 1968, urethroplasty using a penile skin flap has been the mainstay treatment. Unlike the Orandi technique, which used a longitudinal penile skin flap, McAninch $^{[7]}$ suggested a circular fasciocutaneous flap for the reconstruction of a penile urethral stricture in 1993. It is a useful technique with excellent cosmetic and functional outcomes because it is a hairless, flexible tissue having a rich vascular supply from the surrounding tissues. Based on the initial report by McAninch and Morey ${ }^{[8]}$, the overall success rate of a penile circular fasciocutaneous flap was 79\% (52 of 66 patients) with a mean follow-up of 41 months (range: 1 7 years). Later on, Whitson et $\mathrm{al}^{[9]}$ reported the long-term efficacy of the penile circular fasciocutaneous flap for one-stage reconstruction of complex anterior urethral strictures. Recently, Schwentner et al ${ }^{[10]}$ reported a long-term success rate of $90 \%$ in 36 patients who underwent single-stage urethroplasty using the fasciocutaneous flap with a mean follow-up duration of 96.7 months.

In our series of 86 patients who underwent penile circumferential fasciocutaneous flap urethroplasty, the overall success rate was $79 \%$ at 5 years. The success rate of the present study was almost at par with other previous studies. Furthermore, the stricture recurred in 11 cases, of which in 10 , it was located at the fasciocutaneous flap ( Proximal end 6 and distal end 4 ).

Surgical failure was reported in $16.27 \%$ of our patients, wherein focal recurrence occurred mainly at the anastomotic margin, showing results similar to those of previous studies ${ }^{[11,10,7]}$. Many recurrences occurred within the bulbar urethral portion; therefore, it is important to incise the urethra into the normal healthy tissue proximally in order to guarantee a complete stricture incision and adequate exposure. In addition, accurate urethra-flap suture placement is essential for the prevention of recurrence.

Wessells et $\mathrm{al}^{[7]}$ described a combination of tissue transfer techniques to reconstruct long and complex urethral strictures in one stage. These series show a success rate of $88 \%$ in 25 patients with a median follow-up duration of 16 months. Recently, Erickson et al ${ }^{[12]}$ published a success rate of $78.6 \%$ in 14 men who underwent singlestage segmental urethral replacement using a combination of a ventral onlay fasciocutaneous flap with dorsal onlay buccal grafting for long segment strictures. Their surgical outcome was similar to that reported for two-stage repairs. Despite limited cases and short follow-up periods, a combination of tissue transfer techniques for one-stage reconstruction of long complex urethral strictures remains a viable option. Several studies 
have reported that the width of the flap may be changed from 15 to $25 \mathrm{~mm}$ according to the width of the urethral plate ${ }^{(13,10)}$, though we used $20 \mathrm{~mm}$ width for penile skin as onlay flap. The penile skin can be transferred anywhere from the external meatus to the prostatic urethra for urethral reconstruction as a patch or tube ${ }^{(8)}$. If the flap falls short, then it can be combined with other tissue transfer techniques, thus enabling one stage reconstruction in majority of cases $^{(14)}$.

A risk factor analysis revealed that patients with suprapubic cystostomy were more likely to experience surgical failure than patients without. Patients with a severe urethral stricture requiring suprapubic cystostomy might undergo a flap tubularization, which was inferior to onlay reconstruction in terms of the success rate ${ }^{[11]}$. Even in circumcised men, a comparable surgical outcome and good cosmetic results could be attained by using the penile circular fasciocutaneous flap technique ${ }^{[15,11,10]}$. In our experience, there were no effects of circumcision on the risks of recurrence and no penile skin complications.

In our series of 86 patients, the most common complication was dysuria and post-micturition dribbling, due to the increased distensibility of the skin flap as compared to the normal urethra ${ }^{[15]}$. Although further advances in surgical technique are required for the prevention of post-micturition dribbling, management by gentle digital compression seems feasible. The evaluation of the ejaculatory dysfunction reported in 2 cases was difficult due to an insufficient analysis of the preoperative ejaculatory function. In contrast, Sharma et $\mathrm{al}^{[16]}$ reported an improvement in ejaculation and overall satisfaction, while the increased incidence of erectile dysfunction was not definite. Previous authors reported neurovascular complications of lower extremities due to the prolonged high-lithotomy position, particularly in cases where the operation time exceeded 5 hours $^{[11]}$. However, we have not encountered the postoperative compartment syndrome, possibly because the median operation time was 105 minutes (range: 90- 145 minutes) in this series.

In our study, apart from complications listed in Table 2, we did not confront penile torsion, urethral sacculation, diverticulum formation, penile scar or ventral webbing ${ }^{[17]}$. In our study, at the end of $5 \mathrm{yrs}$, the overall success in terms of stricture free rate was $79 \%$. This figure is comparable to $79-86 \%$ reported in different studies ${ }^{[16,11,10,7]}$.

\section{Conclusion}

Penile circular fasciocutaneous flap urethroplasty for a complex anterior urethral stricture showed an acceptable success rate of $68.9 \%$ with or without combined surgery. In addition, the actual stricturefree success rate of fasciocutaneous flap urethroplasty was $79 \%$.in our study. A sufficient, healthy margin should be acquired due to the fact that most of the recurrence occurs at the anastomotic margin of the flap.

\section{References}

1. AK poriaye LE, Schlossberg SM, Jordan GH. Hairless scrotal island flap urethroplasty. J Urol $1995 ; 153$ : 372A

2. Yachia D. Pedicled scrotal skin advancement for one stage anterior urethral reconstruction in circumcised patients. J Urol 1988 ; 139 : 1007-10

3. McAninch JW. Reconstruction of extensive urethral strictures: circular fasciocutaneous penile flap. J Urol 1993; 149 : 488-91.

4. Mundy AR. Management of urethral strictures . Postgrad Med. J.2006 ; 82 : 489-93.

5. Hosseini J, Soltanzadel K. A comparative study of long term results of Buccal mucosal graft and penile skin flap techniques in the management of diffuse anterior urethral strictures: first report in Iran. Urol J. 2004 spring ; $1: 94-8$

6. Orandi A. One-stage urethroplasty. $\mathrm{Br} \mathrm{J}$ Urol. 1968;40:717- 719. [PubMed] 
7. Wessells H, Morey AF, McAninch JW. Single stage reconstruction of complex anterior urethral strictures: combined tissue transfer techniques. J Urol. 1997;157:1271-1274. [PubMed]

8. McAninch JW, Morey AF. Penile circular fasciocutaneous skin flap in 1-stage reconstruction of complex anterior urethral strictures. J Urol. 1998;159:12091213. [PubMed)

9. Whitson JM, McAninch JW, Elliott SP, Alsikafi NF. Long-term efficacy of distal penile circular fasciocutaneous flaps for single stage reconstruction of complex anterior urethral stricture disease. J Urol. 2008;179:2259-2264. [PubMed]

10. Schwentner C, Seibold J, Colleselli D, Alloussi SH, Gakis G, Schilling D, et al. Anterior urethral reconstruction using the circular fasciocutaneous flap technique: long-term follow-up. World J Urol. 2011; 29:115-120. [PubMed]

11. Moradi M, Moradi A. Urethroplasty for long anterior urethral strictures: report of long term results. Urol J. 2006;3:160164. [PubMed]

12. Erickson BA, Breyer BN, McAninch JW. Single-stage segmental urethral replacement using combined ventral onlay fasciocutaneous flap with dorsal onlay buccal grafting for long segment strictures. BJU Int. 2012;109:13921396. [PMC free article] [PubMed]

13. Carney KJ, McAninch JW. Penile circular fasciocutaneous flap to reconstruct complex anterior urethral strictures. Urol .Clin North Am 2002; 29 : 397-401.

14. Dubey D, Kumar A,Bansal P, Srivastava A, Kapoor R, Mandhani A, et al. Substitution urethroplasty for anterior urethral strictures : a critical appraisal of various techniques. BJU Int $2003 ; 91$ : $215-8$.

15. Mercy AF, McAninch JW. Penile circular fasciocutaneous skin flap in one stage reconstruction of complex anterior urethral stricture. J . Urol. 1990 ; 159 : 1209-13.

16. Sharma V, Kumar S, Mandal AK, Singh SK. A study on sexual function of men with anterior urethral stricture before and after treatment. Urol Int. 2011;87:341345. [PubMed]

17. Buckley J, McAninch J. Distal penile circular fasciocutaneous flap for complex anterior Urethral strictures. BJU Int. 2007;100:221-231. [PubMed] 